\section{Monbusho pleads for watered-down agency bill for universities}

\section{Tokyo}

Japan's education ministry last week approved the government's plan to turn national universities into 'agencies' with greater administrative independence, provided that they are allowed to continue to give priority to education and research.

The move would add Japan's 99 national universities to a list of government-run institutions, including museums and national research institutes, that are to be transformed into semiautonomous agencies. The plans are part of the government's bid to increase administrative efficiency by placing the institutions under the control of a separate management system (see Nature 389,$897 ; 1997$ ).

Rather than complying with the government's agency bill, which sets targets based on its rationalization plan, the Ministry of Education, Science, Sports and Culture (Monbusho) is asking for a separate bill for universities to maintain the standard of research and education.

According to the proposed bill, performance-related targets would be reviewed every five years, instead of on the shorter, three- to five-year timescale suggested in the agency bill, and the evaluation be carried out by an independent assessment body that Monbusho plans to set up next April (see Nature 400, 704; 1999).

The proposed bill also promises that some policy decisions, such as the selection of performance-related targets and the appointment of university deans, would reflect the universities' opinions.

Monbusho also insists that university staff should retain their civil-service status, despite pressure from the government to reduce the number of civil servants. The government hoped to reduce Japan's civil servants by 25 per cent in ten years by giving agency status to national universities, which have more than 125,000 staff.

Akito Arima, the education minister, said last week at a meeting of deans of national universities that university reform should be separated from the government's aim to cut central-government employees. "The main aim of the reform is to give the universities more freedom and autonomy, and to enhance their level of education and research," said Arima.

But Monbusho's proposed bill has been criticized by members of the ruling Liberal Democratic Party and government ministries as being too easy on universities. Many expect it to face strong opposition before its final approval next April.

A.S.

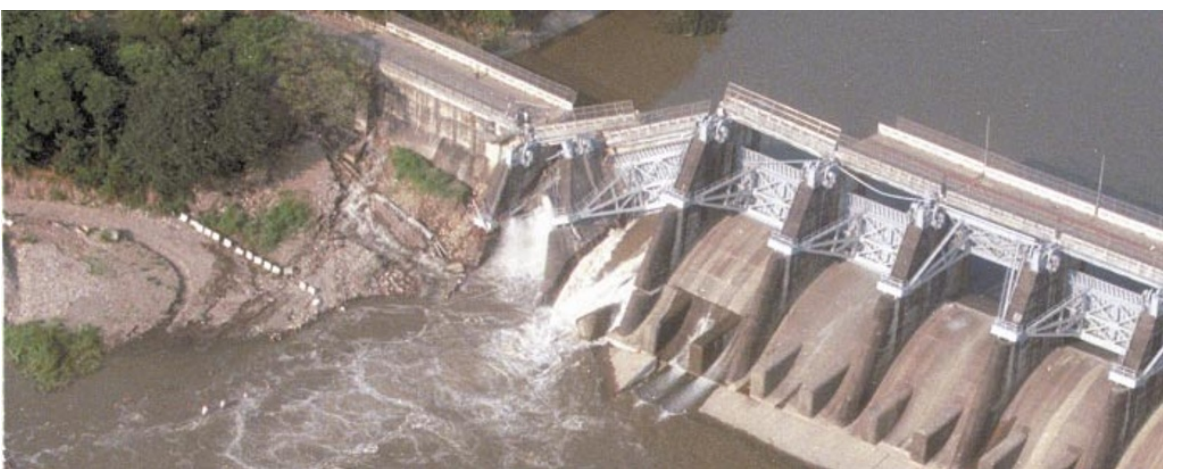

Dambuster: the Shihkang reservoir was damaged by the earthquake that struck Taiwan last week.

\title{
Taiwan's high-tech industries shaken not stirred by quake
}

Tokyo

Last week's earthquake in Taiwan, which killed at least 2,000 people and injured a further 8,000, is likely to damage the nation's high-tech industry, especially its semiconductor companies, which account for seven per cent of the world market.

But officials at the Hsinchu Science Park, where activities were brought to a standstill, predict that the impact will only be short term.

The science park, located in northeastern Taiwan, is home to almost 300 companies and research centres, of which 50 are from overseas, involved in manufacturing integrated circuits and computers, optoelectronics, telecommunications, biotechnology and materials.

Key semiconductor companies reported no serious damage to their facilities. But power cuts and aftershocks are expected to delay the recovery of their operation for another month. Taiwan Electric say the power supply to industrial and business areas is unlikely to return to normal until next week

Industry analysts are predicting a loss of at least NT\$10 billion (US\$315 million) for companies based at the science park and a total loss of NT\$100 billion for Taiwanese industry as a whole. But Steve Hsieh, vicechairman of Taiwan's National Science Council, says that almost half of the park's losses can be recovered this year as the earthquake actually caused very little damage.

In Japan, where many electronics companies import semiconductors and liquidcrystal devices from Taiwan, there is concern that the earthquake could lead to a serious shortage of computer parts - the price of semiconductors in Japan increased by 20 per cent immediately after the earthquake.

"We have to rethink our strategy, as delayed production [of computers] could affect Japan's ability to tackle the Y2K problem" (the 'millennium bug'), says a spokesman from Toshiba, a Japanese company that makes its semiconductors in Taiwan.

Although the earthquake had a substantial effect on Taiwan's industry, research at universities and research institutes seems to have escaped. Hsieh says that 8,000 private researchers at the Hsinchu Science Park have resumed their activities, and that the two universities near the park were unaffected.

"Some of the institutions in central Taiwan, such as the Agricultural Research Institute, experienced damage to their buildings and equipment, but the overall loss is likely to be only around NT\$100 million, and their core research activity is unlikely to be affected," says Hsieh.

Meanwhile, seismologists and engineers from around the world are flocking to Taiwan to analyse the impact of the earthquake and to assess the structures of the collapsed buildings.

The earthquake on 20 September, which measured 7.7 on the open-ended Richter scale at the epicentre in central Taiwan, caused widespread damage, destroying roads and buildings and depriving people of electricity, telephone and water for days.

As over 1,000 aftershocks ricocheted across the country, more buildings - mainly new high-rise apartment blocks - collapsed, revealing substandard construction that did not comply with Taiwan's strict earthquake building codes.

This failure is being blamed on the construction boom that accompanied Taiwan's rapid economic development over the past decade. Many of the damaged buildings had their structures above the lower levels intact, implying weak, shoddy construction at the base.

According to Hiroyuki Kameda, professor of earthquake engineering at Kyoto University, Taiwan had toughened its building rules following the earthquake in Kobe, Japan, in 1995. But buildings completed during the earlier construction boom were not required to meet such standards.

Asako Saegusa 